\title{
Quality and durability properties and life-cycle assessment of high volume biomass fly ash mortar
}

\author{
E.R. Teixeira ${ }^{\text {a,* }}$, R. Mateus ${ }^{a}$, A. Camões ${ }^{a}$, F.G. Branco ${ }^{b}$ \\ ${ }^{a}$ CTAC, Department of Civil Engineering, School of Engineering, University of Minho, Campus de Azurém, 4800-058 Guimarães, Portugal \\ ${ }^{\mathrm{b}}$ ISISE - Coimbra, Department of Civil Engineering, University of Coimbra, Rua Luís Reis Santos - Pólo II da Universidade, 3030-788 Coimbra, Portugal
}

\section{H I G H L I G H T S}

- Environmental benefits of incorporating coal and biomass fly ashes on concrete.

- Coal and biomass fly ashes were incorporating on mortar as cement replacement.

- Biomass fly ash were used as reservoir of alkalinity.

- Mortars with BFA and CFA have good quality, durability and sustainability.

- BFA can lead to a minimization of the issues related to the HVFAC.

\section{A R T I C L E I N F O}

\section{Article history:}

Received 9 July 2018

Received in revised form 12 October 2018

Accepted 22 November 2018

\section{Keywords:}

Biomass fly ash

Carbon dioxide

Carbonation

Compressive strength

Mortars

\begin{abstract}
A B S T R A C T
The effect of using biomass fly ash (BFA) on the quality, durability and sustainability of mortars was studied. Using high amounts of BFA does not lead to a production of mortars with better performance than a plain cement mortar. However, when BFA is used in small amounts mixed with coal fly ash, mortars with similar compressive strength, to that of a cement mortar, but with less carbonation and with better environmental performance are obtained. Using BFA in the concrete industry can lead to a minimisation of issues related to the high volume fly ash concrete.
\end{abstract}

(c) 2018 Elsevier Ltd. All rights reserved.

\section{Introduction}

Concrete is a building material that is used for innumerable large infrastructure developments [1]. In terms of sustainability, one of the major issues related to the concrete industry is $\mathrm{CO}_{2}$ emissions resulting from cement production [2]. Some authors affirm that during the production of $1000 \mathrm{~kg}$ of clinker, about $866 \mathrm{~kg}$ of $\mathrm{CO}_{2}$ is generated [2], which corresponds to $5-8 \%$ of all $\mathrm{CO}_{2}$ produced by mankind [1,3]. Moreover, $60 \%$ of these emissions result from limestone calcination, which is the main raw material for cement production $[1,2]$. The fuel used to generate heat (by combustion) for the necessary reactions to produce the clinker minerals accounts for the remaining $\mathrm{CO}_{2}$ emissions [2].

A report [4] developed by business leaders and academics about construction materials showed that one of the most important opportunities for $\mathrm{CO}_{2}$ emission reduction is using a low-carbon cement. The authors emphasise that to reduce $1 \mathrm{GT}$ of $\mathrm{CO}_{2}$, by 2020 in the concrete sector, 50\% of Portland cement used in concrete will need to be replaced by a low-carbon alternative [4]. Certainly, only this solution alone does not lead to such levels of $\mathrm{CO}_{2}$ reduction, and the construction industry needs to adopt an integrated approach, which involves using less cement in new constructions, a decrease in cement consumption, mainly in the concrete production and a reduction in the clinker consumption to produce cements [5].

In order to reduce the environmental impact of the concrete industry, several options need to be considered, and increasing the use of supplementary cementitious materials (SCM) is one of them $[1,2]$. Using these materials already happens in a large extension [1]. However, incorporating high volumes of fly ash leads to a formation of hydrated binders with a low calcium hydroxide content, which decreases the concrete alkalinity and may lead to less durable materials [6,7]. Hence, utilising wastes or sub-products

\footnotetext{
* Corresponding author.
} 
that can compensate alkalinity losses resulting from replacing cement is a solution that must be addressed.

Nowadays, using renewable sources, such as forestry biomass to produce energy has been increasing. Biomass is converted to energy by combustion, leading to a major problem that is fly ash production. Fly ash is an environmental pollutant, requiring very expensive management [8]. As a result, its use as a cement replacement in concrete can decrease the cement needs [9], while minimising the issues associated to the high volume cement replacement, since these ashes are more alkaline [10]. Some studies have been carried out and showed good results when biomass fly ash was used as cement replacement material [11-13].

The focus of this study is to understand if BFA can be an alternative solution for issues related with high volume fly ash concrete (HVFAC), mainly related with the decrease on the alkaline content, when cement is replaced by high fly ash amounts. To broaden the knowledge about the effect of BFA on the quality, durability and sustainable properties of concrete, and since in some studies is showed that the results obtained for the properties of conventional concrete, e.g. mechanical resistance, are coincident with the results obtained in the corresponding mortars. A group of high volume fly ash mortars was prepared by incorporating BFA alone or blended with coal fly ash as cement replacement material. The effect of BFA on the workability, mechanical resistance, porosity, carbonation resistance, in different curing periods, was studied.

The development of low carbon footprint mortar with the aim of reducing the environmental impact of the Portland cement production is one of the most important goals of the work developed. It is important to analyse and compare the potential environmental impacts related to the production of plain cement mortars and the impacts resulting from the production of materials that uses BFA (alone or blended with coal fly ash or/and hydrated lime) as raw material substitution. One of the best approaches to develop this type of study is to use the life cycle assessment (LCA) method [14]. This method makes it possible to quantify the potential environmental impacts of products or services. It quantifies both the input flows, such as energy, water and materials, as well as the output flows, such as $\mathrm{CO}_{2}$ emissions, solid wastes and liquid wastes $[2,15]$. LCA can estimate the potential impact on humans and on the environment and can also identify areas with improvement potential [2]. Based both on the abovementioned context and methodological approach, this study quantified and compared the potential environmental impacts resulting from the production of different mortar formulations.

As BFA is an alkaline waste, it was also studied if slight amounts of BFA contribute to mitigating the problems of alkalinity found in HVFAC and the results were compared with the results obtained for mortars with hydrated lime, since hydrated lime is an alkaline material, which in some studies reveals good results for this problem.

\section{Materials}

In the preparation of all high volume fly ash mortar mixtures, the main goal was to reduce the cement content in order to increase the environmental performance at least while maintaining the quality and durability properties. The powder materials used in the mixes were Portland cement CEM I 42.5R (from Secil company, Outão, Portugal) (C), coal fly ash (CFA), biomass fly ash (BFA) and hydrated lime (HL) (from the Portuguese company Lusi(al). The physical and chemical composition of the hydrated lime stated in the product datasheet is presented in Table 1.

The coal fly ash was obtained from a Portuguese thermoelectric power plant. The biomass fly ash was obtained from a Portuguese thermal power plant which used forest residues, such as bark from
Table 1

Physical and chemical characteristic of hydrated lime.

$\begin{array}{ll}\text { Granulometric: retained in } 125 \mu \mathrm{m} & \leq 0.0 \% \\ \text { Free water content } & \leq 1.0 \% \\ \text { Stability (expansion) } & \leq 0.2 \% \\ \mathrm{Ca}(\mathrm{OH})_{2} \text { content } & \geq 93.0 \% \\ \mathrm{MgO} \text { content } & \leq 3.0 \%\end{array}$

eucalyptus and pine as fuel to produce heat and power [16]. Fig. 1 shows the particle size distributions of the powder materials assessed, in a liquid environment, by laser diffraction using CILAS 920 equipment. In general, cement and CFA had much finer particles when compared with BFA and the average diameter of BFA particles was around $47 \mu \mathrm{m}$. The density of cement, hydrated lime, CFA and BFA were $3130,2230,2420$ and $2619 \mathrm{~kg} / \mathrm{m}^{3}$, respectively and was determined according to [17].The chemical composition of the materials is presented in Table 2.

As can be seen, BFA showed a LOI value of $6.27 \%$ and CFA presented a value of $2.73 \%$. According to the standard [18], which defines and reports the specifications and conformity criteria for fly ash incorporation in concrete, in terms of loss-on-ignition, BFA belongs to category $\mathrm{B}$ ( $\mathrm{LOI} \leq 7 \%$ ) and CFA belongs to category $\mathrm{A}(\mathrm{LOI} \leq 5 \%)$. $\mathrm{SiO}_{2}$ was the major chemical element $(>25 \%$, dry bs) presented in the CFA, followed by $\mathrm{Al}_{2} \mathrm{O}_{3}, \mathrm{Fe}_{2} \mathrm{O}_{3}, \mathrm{CaO}$ and $\mathrm{K}_{2} \mathrm{O}$. In contrast, $\mathrm{CaO}$ was the major chemical present in BFA (>19\% dry bs), followed by $\mathrm{SiO}_{2}, \mathrm{Al}_{2} \mathrm{O}_{3}, \mathrm{~K}_{2} \mathrm{O}, \mathrm{Fe}_{2} \mathrm{O}_{3}, \mathrm{MgO}$. One of the criteria of [18] is that the sum of $\mathrm{SiO}_{2}, \mathrm{Al}_{2} \mathrm{O}_{3}$ andFe $\mathrm{O}_{3}$ needs to be higher than $70 \%$. In relation to this criterion only CFA meets this requirement.

The pozzolanic activity index was determined according to [18]. Mortars with $75 \%$ wt of cement and $25 \%$ wt of CFA/BFA were prepared and tested for mechanical strength after 28 and 90 days of curing. According to the standard, the pozzolanic activity index at 28 and 90 days cannot be below $75 \%$ and $85 \%$, respectively. As can be seen, the CFA meets the requirements of the standard on contrary BFA has an index lower than required for 90 days (Table 3). However, BFA did not presented a high pozzolanic activity index is one of the most type of biomass ash produced in Portugal. BFA is also a very alkaline waste and several studies showed that BFA can be solution for problems related with HVFAC [19-21]. For that reasons, it was decided to use this BFA for this study.

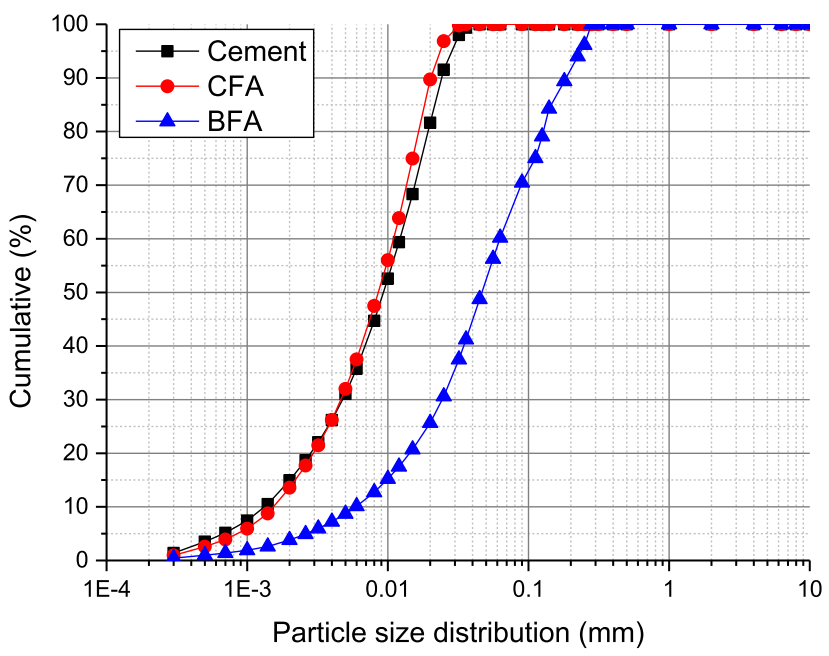

Fig. 1. Particle size distribution of Portland cement, coal fly ash and biomass fly ash [16]. 
Table 2

Chemical composition of materials (oxides, \% by weight).

\begin{tabular}{llll}
\hline Oxides & CFA & BFA & Cement \\
\hline $\mathrm{SiO}_{2}$ & 54.1 & 36.1 & 15.9 \\
$\mathrm{CaO}$ & 3.3 & 28.0 & 52.9 \\
$\mathrm{Na}_{2} \mathrm{O}$ & 0.5 & 0.9 & 0.8 \\
$\mathrm{Al}_{2} \mathrm{O}_{3}$ & 26.4 & 8.4 & 3.3 \\
$\mathrm{MgO}$ & 1.6 & 3.5 & 4.4 \\
$\mathrm{~K}_{2} \mathrm{O}$ & 1.6 & 5.4 & 7.4 \\
$\mathrm{Fe}_{2} \mathrm{O}_{3}$ & 6.1 & 4.1 & 2. \\
$\mathrm{P}_{2} \mathrm{O}_{5}$ & 0.8 & 3.2 & 1.1 \\
$\mathrm{TiO}_{2}$ & 1.4 & 0.9 & 0.3 \\
$\mathrm{MnO}$ & 0.05 & 0.2 & 0.9 \\
$\mathrm{LOI}$ & 2.73 & 6.27 & 2.34 \\
\hline
\end{tabular}

Table 3

Pozzolanic activity index.

\begin{tabular}{lll}
\hline Sample & 28 days & 90 days \\
\hline CFA & 76.0 & 87.9 \\
BFA & 76.1 & 75.0 \\
\hline
\end{tabular}

The aggregate used for mortar preparation was a commercial river rolled sand $0 / 4 \mathrm{~mm}$. Additionally, a polycarboxylic ether superplasticizer, called Glenium Sky 617, was used. No other chemical admixtures and no viscosity-modifying admixtures were used. In the preparation of some formulations, it was used hydrated lime (from the Lusical industry) was used as an addition, with the main goal of given the alkalinity lost due to the cement substitution by high amounts of coal fly ash.

\section{Experimental and analytical methods}

\subsection{Mortar formulations}

The mortar mixture formulations are shown in Table 4. The mixtures differ in the proportion of powder materials, waterbinder ratio and the content of superplasticizer (due to the workability requirements for the mortar). All mixtures were prepared with 1 mass basis (wt) part of binder (taken as the sum of cement, fly ash and hydrated lime): $2.5 \mathrm{wt}$ parts of aggregate. These proportions were chosen due to the fact that the main aim of this study is to find a solution for the conventional concretes, and usually the cement dosage on a conventional plain cement concrete is around $300 \mathrm{~kg} / \mathrm{m}^{3}$ and the content of sand is equal to $750 \mathrm{~kg} / \mathrm{m}^{3}$ with a water/binder ratio of 0.5 . These proportions for mortar production were chosen taking into account published studies that show that the results obtained for the properties of conventional concrete are coincident with the results obtained in the corresponding mortars.

A plain cement mortar (REF), with a water/binder ratio of 0.5 , was used as the reference for the results obtained in this study in the different properties. This formulation was chosen as the reference since it represents a conventional concrete (where the cement dosage is around $300 \mathrm{~kg} / \mathrm{m}^{3}$ and with a $\mathrm{w} / \mathrm{b}=0.5$ ), and in this study the aim is to have a much more eco-efficient alternative to these concretes, which are generally used.

It is known that a high volume fly ash concrete can be a feasible alternative for the plain cement concrete replacement. This type of concrete is produced using low cement content and can be done with a low w/b ratio (with less water content), while maintaining similar mechanical strength and improving the durability and the sustainability level. As the focus of this work is to find a more eco-efficient HVFAC solution than the plain cement mortar, three formulations with $50 \%$ of cement replacement by coal fly ash, biomass fly ash and a blend with the two ashes were studied (Table 4 - Mixtures: CFA50, BFA50 and CFA25BFA25), with a binder content of $300 \mathrm{~kg} / \mathrm{m}^{3}$ but with a low w/b ratio than the reference $(0.35)$. It is important to referrer that the content of each material per $\mathrm{m}^{3}$ of mortar produced was calculated taken into account the density of each material.

On the other hand, one of the issues related to high volume fly ash concrete is the possibility of reinforcement corrosion that may be associated to its worst carbonation behavior. As BFA are more alkaline than CFA, small amounts of BFA (0.5, 1.3 and 5\%wt) blended with coal fly ash were also studied to verify if it is possible to improve the alkalinity of those mortars and their carbonation resistance. A comparison with the utilisation of hydrated lime for the same purpose was also carried out, since it was showed in other studies [22] that the introduction of lime minimises the issues related to $\mathrm{pH}$ decreased by preventing the loss of alkalinity. It was study small amounts of $\mathrm{HL}(0.5,1.3$ and $5 \% \mathrm{wt})$ once in other studies it was seen that the best results were achieved when it is used small amounts, as e.g. the higher carbonation resistance was observed for samples with 2.5 and $5 \%$ wt of hydrated lime [23]. In all remaining formulations, the proportion of cement replacement was $50 \%$ by weight with a water/binder ratio of 0.35 .

Table 4

Mortar mixture proportions.

\begin{tabular}{|c|c|c|c|c|c|c|c|}
\hline \multirow[t]{2}{*}{ Mixtures } & \multirow[t]{2}{*}{ C-CFA-BFA-HL } & \multicolumn{4}{|c|}{ Materials $\left(\mathrm{kg} / \mathrm{m}^{3}\right)^{\mathrm{a}}$} & \multirow[t]{2}{*}{$\mathrm{w} / \mathrm{cm}$} & \multirow[t]{2}{*}{$\mathrm{SP}(\%)$} \\
\hline & & $\mathrm{C}$ & CFA & BFA & $\mathrm{HL}$ & & \\
\hline \multirow[t]{4}{*}{ Control mixtures } & REF & 300 & - & - & - & 0.50 & 0.00 \\
\hline & CFA50 & 150 & 117 & - & - & 0.35 & 0.25 \\
\hline & BFA50 & 150 & - & 127 & - & 0.35 & 1.25 \\
\hline & CFA25BFA25 & 150 & 59 & 63 & - & 0.35 & 0.50 \\
\hline \multirow[t]{9}{*}{ Ternary HVFA blends } & CFA49.5HL0.5 & 150 & 116 & - & 1 & 0.35 & 0.25 \\
\hline & CFA48.8HL1.3 & 150 & 114 & - & 3 & 0.35 & 1.25 \\
\hline & CFA45HL5 & 150 & 105 & - & 11 & 0.35 & 1.25 \\
\hline & BFA49.5HL0.5 & 150 & - & 125 & 1 & 0.35 & 0.25 \\
\hline & BFA48.8HL1.3 & 150 & - & 124 & 3 & 0.35 & 1.25 \\
\hline & BFA45HL5 & 150 & - & 114 & 11 & 0.35 & 1.25 \\
\hline & CFA49.5BFA0.5 & 150 & 116 & 1 & - & 0.35 & 1.25 \\
\hline & CFA48.8BFA1.3 & 150 & 114 & 3 & - & 0.35 & 1.25 \\
\hline & CFA45BFA5 & 150 & 105 & 13 & - & 0.35 & 0.25 \\
\hline \multirow[t]{3}{*}{ Multiple HVFA blends } & CFA49.5BFA0.3HL0.3 & 150 & 116 & 1 & 1 & 0.35 & 0.25 \\
\hline & CFA48.8BFA0.6HL0.6 & 150 & 114 & 2 & 1 & 0.35 & 0.50 \\
\hline & CFA45BFA2.5HL2.5 & 150 & 105 & 6 & 5 & 0.35 & 0.50 \\
\hline
\end{tabular}

${ }^{\mathrm{a}}$ Keys: $\mathrm{w} / \mathrm{cm}=$ water/cementitious materials ratio; $\mathrm{C}=$ cement; $\mathrm{CFA}=$ coal fly ash; $\mathrm{BFA}=$ biomass fly ash; $\mathrm{HL}=$ hydrated lime; $\mathrm{SP}=$ superplasticizer. 


\subsection{Experimental procedures}

The tests were conducted to assess the workability, mechanical strength and durability properties. The experimental procedures include, for each mixture, the evaluation of the flow spread, fresh density, air content, flexural and compressive strength, water absorption and carbonation resistance.

\subsubsection{Workability, density and air volume content}

To assess the properties of the fresh mortar, the flow spread test was carried out according to [24]. The fresh bulk density was evaluated according to [25] and the air volume content of fresh mortar was measured according to [26].

\subsubsection{Mechanical resistance}

Flexural and compressive strength of the mortars were determined at $7,28,56,90$ and 180 days on $40 \times 40 \times 160 \mathrm{~mm}^{3}$ prisms according to [27]. The flexural strength was carried out in a LLOYDS Instruments universal testing machine, with a maximum capacity of $50 \mathrm{kN}$. The compressive strength was performed in an ELE Auto Test press, with a capacity between 5 and $110 \mathrm{kN}$. The results reported show the average value of three samples for each mixture and curing period.

\subsubsection{Water absorption}

The water absorption test was evaluated by an immersion test and by a capillarity test, in samples with 28,90 and 180 days of curing. To measure the water absorption, $40 \times 40 \times 160 \mathrm{~mm}^{3}$ samples were previously submitted to a flexural test, which divided each prism into two similar parts. Then, one part of the specimen was used for the capillarity test and the other was used for the immersion test. All mortar parts were dried until constant mass. For the water immersion test, the specimens were immersed in water and weighed every $24 \mathrm{~h}$ until the weight stabilisation which is achieved when the difference between two consecutive measurements is less than $0.1 \%$ of weight. This test quantifies the open porosity, measured according to [28,29] and is described in more detail in [16].

The water absorption by capillarity is characterised by the coefficient of capillarity, which is obtained by calculating the slope of the linear regression line, which links the points related to the weight measures carried out between 10 and 90 min of testing, in a square time root. This test was performed according to [30] and described in more detail in [16].

\subsubsection{Carbonation resistance}

The accelerated carbonation test was carried out on $40 \times 40 \times 160 \mathrm{~mm}^{3}$ samples with $28,90,180,270$ and 360 days of curing period, according to [31]. After curing, the samples were preconditioned in an isolated container with temperature and relative humidity control for a period of 14 days $(80.8 \pm 6.5 \% \mathrm{RH}$ and $24.2 \pm 2.2^{\circ} \mathrm{C}$ ). This ensures the stabilisation of the humidity inside the samples. Then, samples were sealed with paraffin with the exception of two opposite faces and introduced in the accelerated carbonation chamber, with $4.2 \pm 0.1 \%$ wt of $\mathrm{CO}_{2}, 52.6 \pm 8.3 \% \mathrm{RH}$ and $20.0 \pm 0.8^{\circ} \mathrm{C}$. The carbonation depth was determined by spraying $1 \%$ of phenolphthalein in the solution of $70 \%$ alcohol on a broken surface [32]. This indicator is colourless and used as an acid-base indicator. The colour of phenolphthalein changes into pink/carmine red when $\mathrm{pH}$ is higher than approximately 9. Therefore, when the solution is sprayed on the broken surface of the mortar, the zone that is carbonated is uncoloured and the zone that is not carbonated presents a pink/carmine red colour [32]. The values for the depth of carbonation are taken from an average of 10 measurements.

\subsection{Environmental assessment of mortar mixes}

\subsubsection{Goal and scope}

The main goal was to evaluate the environmental performance of the mortar formulations using biomass fly ash as a cement replacement and as an alkaline material. The method used in this study followed the phases of a Life Cycle Assessment (LCA) phases: goal and scope definition, inventory analysis and impact assessment. The comparative analysis and the aggregation of indicators were developed using the multi-criteria decision support Methodology for the Relative Sustainability Assessment of Building Technologies [33-35]. The MARS-SC methodology is based on three groups of sustainability categories: environmental, functional and economic [34,35]. Since this research is aimed at assessing the environmental performance of the differently produced mortars, only the environmental category of the MARS-SC was considered in this study.

\subsubsection{Functional unit and system boundaries}

The functional unit was $1 \mathrm{~m}^{3}$ of ready-mixed mortar, which is the basis for comparison throughout the study. A cradle-to-gate analysis of the potential environmental impacts is carried out and the boundaries of this study included the extraction of raw materials for mortar production and preparation processes (cement, aggregates, admixtures, coal fly ash, biomass fly ash and hydrated lime), transportation of materials, mixing of mortar materials and ends at the mortar plant with the final product ready to be used in the construction field.

\subsubsection{Inventory analysis}

The inventory analysis is used to quantify the inputs (e.g. energy, materials and chemical) and outputs (e.g. emissions and waste) of the product system [36]. Table 5 shows the inventory of the materials and transportation considered for the specific context of the Portuguese mortar industry. The life cycle analysis software SimaPro 8.4.0.0 was used for the quantification of the impact categories.

The consumption of raw materials, energy and fuel and the emissions released during cement production of a Portuguese cement plant were considered. The used source of information was the public Environmental Declaration of the selected cement plant [37].

For the coal fly ashes, a private Portuguese power plant, from which the used fly ashes were coming from, was considered. The power plants produce electricity and fly ashes as a co-product. Therefore, it was necessary to make the allocation of the flows of the power plant, according to the methodology proposed by other studies, such as [38]. In the present study, an economic allocation process, based on the market value of each power plant's product was carried out. A more detailed explanation of the used methodology can be found in [35]. In this study, the economic allocation coefficient of $0.17 \%$ was applied to the impacts of the extraction, transportation, and combustion of the coal on the power plant, in the calculation of the fly ash related potential environmental impacts.

In Portugal, biomass fly ash is classified as a waste product and thus does not afford an economic value. Therefore, according to the allocation rules set out by [39], no flows from the biomass thermal power plant were allocated to its production, and only the transportation from the BFA production to the mortar production was considered.

For the other materials used in the mixtures (sand, hydrated lime and superplasticizer), transportation processes and production processes, generic data from the life-cycle inventory database Ecoinvent report V3 [40] was used. This database covers the average inventory data of the main building materials and processes in 


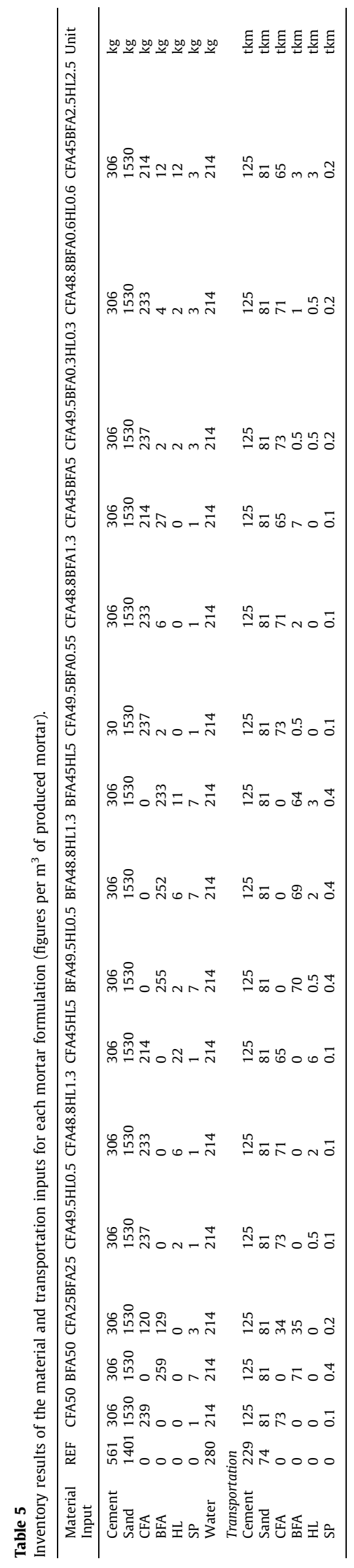

Table 6

Indicators, units and quantification methods.

\begin{tabular}{|c|c|c|}
\hline Environmental indicators & Units & LCIA methods \\
\hline Global warming (GWP 100) & {$\left[\mathrm{kg} \mathrm{CO} \mathrm{CO}_{2}\right.$ eq] } & $\begin{array}{l}\text { CML } 2 \text { baseline } \\
2000 \text { V2.05 }\end{array}$ \\
\hline Ozone layer depletion (ODP) & [kg CFC-11 eq] & $\begin{array}{l}\text { CML } 2 \text { baseline } \\
2000 \text { V2.05 }\end{array}$ \\
\hline Acidification potential (AP) & {$[\mathrm{kg} \mathrm{SO} \mathrm{Seq} \mathrm{eq}$} & $\begin{array}{l}\text { CML } 2 \text { baseline } \\
2000 \text { V2.05 }\end{array}$ \\
\hline Eutrophication potential (EP) & {$\left[\mathrm{kg} \mathrm{PO}_{4} \mathrm{eq}\right]$} & $\begin{array}{l}\text { CML } 2 \text { baseline } \\
2000 \text { V2.05 }\end{array}$ \\
\hline $\begin{array}{l}\text { Formation potential of } \\
\text { tropospheric ozone (POCP) }\end{array}$ & {$\left[\mathrm{kg} \mathrm{C}_{2} \mathrm{H}_{4} \mathrm{eq}\right]$} & $\begin{array}{l}\text { CML } 2 \text { baseline } \\
2000 \text { V2.05 }\end{array}$ \\
\hline $\begin{array}{l}\text { Abiotic depletion potential of } \\
\text { fossil resources (ADP_FF) }\end{array}$ & [MJ eq] & $\begin{array}{l}\text { Cumulative energy } \\
\text { demand V1.09 }\end{array}$ \\
\hline
\end{tabular}

Table 7

Flow spread diameter (d), fresh density and air volume content present in each mortar formulation.

\begin{tabular}{llll}
\hline Mortar & $\mathrm{d}(\mathrm{mm})$ & $\rho\left(\mathrm{kg} / \mathrm{m}^{3}\right)$ & $\mathrm{Vv}(\%)$ \\
\hline REF & 203 & 2232 & 2.8 \\
CFA50 & 150 & 3381 & 4.4 \\
BFA50 & 138 & 3367 & 5.1 \\
CFA25BFA25 & 142 & 3389 & 5.0 \\
CFA49.5HL0.5 & 147 & 3432 & 3.6 \\
CFA48.8HL1.3 & 146 & 3453 & 3.8 \\
CFA45HL5 & 141 & 3436 & 3.5 \\
BFA49.5HL0.5 & 142 & 3386 & 4.8 \\
BFA48.8HL1.3 & 145 & 3361 & 6.0 \\
BFA45HL5 & 153 & 3390 & 4.3 \\
CFA49.5BFA0.5 & 155 & 3420 & 3.8 \\
CFA48.8BFA1.3 & 147 & 3430 & 3.8 \\
CFA45BFA5 & 145 & 3431 & 4.0 \\
CFA49.5BFA0.3HL0.3 & 151 & 3427 & 3.7 \\
CFA48.8BFA0.6HL0.6 & 161 & 3410 & 5.0 \\
CFA45BFA2.5HL2.5 & 150 & 3429 & 4.1 \\
\hline
\end{tabular}

different regional contexts [34]. For each considered process from this database, a contextualisation for the Portuguese energy mix context was made. The reason for this is the fact that the Portuguese energy mix for electricity production is different from the European average [35,41,42]. Therefore, all used processes from the Ecoinvent database were edited and the electricity input flows were changed to taken into account the Portuguese energy mix.

\subsubsection{Impact assessment}

In this stage, the classification, characterisation, and normalisation of impact categories are carried out [2]. The life cycle inventory data was converted into potential environmental impact, using the life-cycle impact assessment methods. In MARS-SC, the environmental performance assessment is based on the following environmental impact categories (Table 6): global warming, ozone depletion, acidification of soil and water, eutrophication, photochemical ozone creation and depletion of abiotic resources-fossil fuels. Compared with the list of the impact categories found in the EN15804:2012 [43] standard, MARS-SC does not consider the depletion of abiotic resources elements as an impact category.

3.3.4.1. Normalisation and aggregation. In order to avoid the scale effects in the aggregation of parameters of the different indicators and to minimise the possibility that some of the parameters are of the type "higher is better" and others "lower is better", the indicators need to be normalised [34]. The normalisation of indicators was carried out as described in [34,35].

The aggregation of each environmental indicator in terms of a global indicator, describing the overall environmental perfor- 
mance was done and the procedure is described in [35]. The results are presented in a "radar" or Amoeba diagram, also known as a sustainable profile. In the diagram, the number of rays equals the number of indicators that are analysed [35]. In each sustainable profile, the global performance of a respective mortar with coal/ biomass fly ash and/or hydrated lime is monitored and compared with the reference mortar (Table 5).

\section{Results and discussion}

\subsection{Flow spread, fresh density and air volume content}

The flow spread diameter (d), the fresh density $(\rho)$ and air voids (Vv) content of the mortar mixtures are presented in Table 7. According to the flow spread results, all mixtures with the two types of fly ash had lower values than the reference, which uses only cement as binder. This is a result of the decrease in the water/binder ratio and can be surpassed by using a superplasticizer. The dosage of superplasticizer was adjusted by trial and error to obtain a flow spread between a class ranges of 140-160 mm and the obtained values are presented in Table 4. However, it is important to refer that there is a significant difference in the $w / b$ between the reference and the others mortar formulations and this can have an influence on the viscosity of mortars, and consequently on its workability. Mortars with biomass fly ash presented the lower diameter values. This is due to the fact that wood fly ash presents a heterogeneous distribution of particles, with irregular shape and fineness, which leads to a high specific surface area and controls the compactness of mixtures [44,45]. Additionally, the high loss on ignition (Table 2), that shows a high organic matter in the BFA composition, which can lead to an adsorption of water molecules and result in a decrease in the free water available for workability $[21,44,46]$.

The density of the fresh mixtures with ash was higher than the reference mixture. However, no significant differences in fresh density were observed among the mixtures containing ash. The decrease in the water/binder ratio led to an increase in the air voids content, and the highest values observed in the mixtures with the incorporation of high biomass fly ash content (Table 7).

\subsection{Mechanical resistance}

Fig. 2 presents the average flexural strength values for all mortar mixtures. The replacement of cement by CFA, BFA or/and a blend of the two types of ash led to similar or higher values on the flexural strength, when compared with the mortar made only with cement (REF) after 28 days of curing. This is due to the



Fig. 3. Compressive strength development over time.

decrease in the water/binder ratio, and it is known that a decrease in the water/binder leads to a gain in strength [47].

Fig. 3 presents the average compressive strength values for all mortar mixtures. It was observed that up to 90 days of curing, the reference mortar had the highest values for the compressive strength. After that period, the $50 \%$ of cement replacement by CFA and by a mixture of $25 \%$ of CFA and $25 \%$ of BFA presented similar values to $100 \%$ of cement mortar. The introduction of fly ash leads to a delay in the hydration process, which leads to a retardation on compressive strength increase [20]. One important observation was that mortars with fly ash blended with low biomass fly ash content led to higher values of compressive strength than when only coal fly ash was used as a cement replacement material. However, with hydrated lime, similar behavior is observed for the mortar with $1.25 \%$ wt of HL. The improvement of compressive strength can be due to CFA particles breaking down at high calcium hydroxide content and the inner silicate phase becoming suitable for the reaction and the production of more calcium silicate hydrates [48]. In general, the mixtures with CFA with HL presented the highest values followed by mixtures with CFA with BFA or BFA and HL and followed by the mixtures with BFA and HL.

The utilisation of BFA and HL blended does not lead to mortars with good mechanical characteristics. These were the lowest values for all mortars observed for all mortars tests.

In terms of mixtures with coal fly ash, biomass fly ash and hydrated lime, up to 90 days of curing the values observed for compressive strength were similar or higher than mortars produced only with cement and coal fly ash. At 180 days, mortars with $0.25 \%$ of BFA and $0.25 \%$ of $\mathrm{HL}$ and $0.625 \%$ of BFA and $0.625 \%$ of HL presented values for compressive strength similar to mortars



Fig. 2. Flexural strength development over time for each mortar formulation.

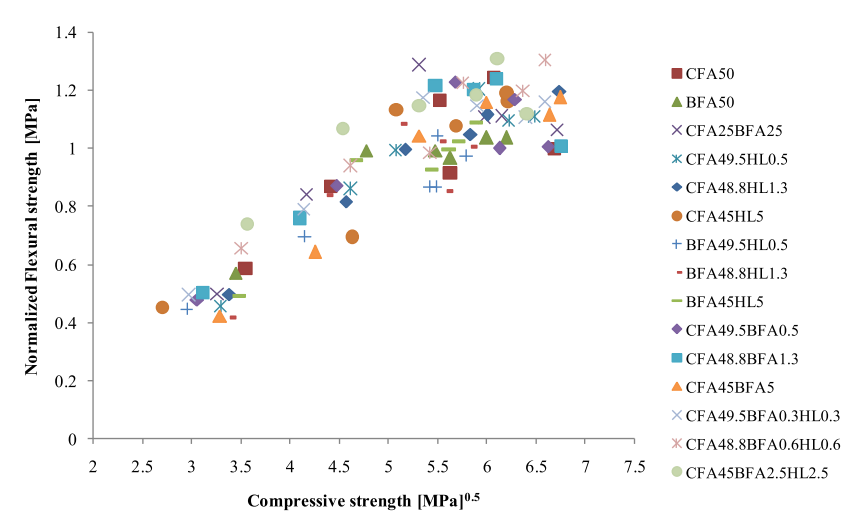

Fig. 4. Relationship between flexural strength and the square root of compressive strength of studied mortars. 


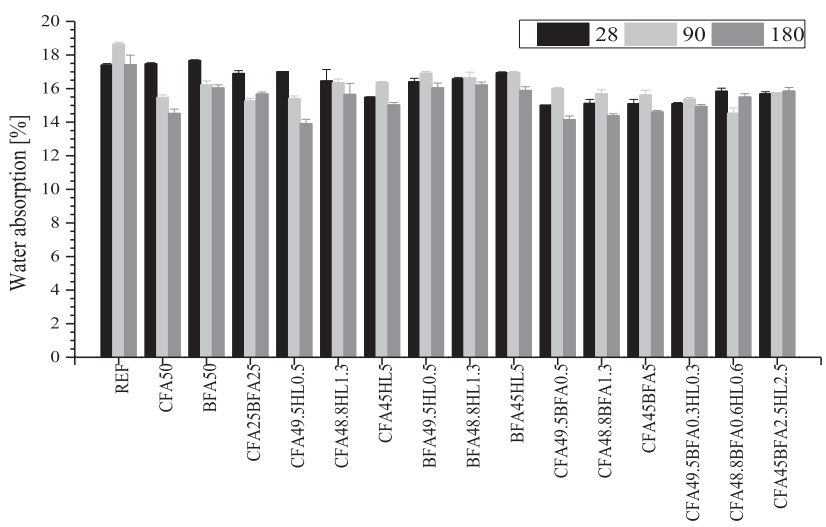

Fig. 5. Total porosity of samples determined by water absorption by immersion.

with $50 \%$ of CFA. Is important to note that there are several formulations (BFA50, CFA25BFA25, CFA49.5HL0.5, CFA48.8HL1.3, CFA49.5BFA0.5, CFA48.8BFA1.3, CFA45BFA5, CFA49.5BFA0.3HL0.3, CFA48.8BFA0.6HL0.6 and CFA45BFA2.5HL2.5), which after 90 days can result in mortars with a similar or higher compressive resistance than a plain cement mortar, but with a replacement of cement of $50 \% \mathrm{wt}$.

The relationship between the normalized flexural strength and the square root of compressive strength was also analysed for the studies mortars (Fig. 4). It was observed that there was a direct relationship between the compressive and flexural strength of a given mortar, showing once again that compressive strength can be assumed as an adequate index for all types of strength [49]. However, is possible to verify that this relationship is affected by other parameters, such as the type of binder.

\subsection{Durability analysis}

\subsubsection{Water absorption}

The results for the open porosity obtained by water immersion analysis are presented in Fig. 5. The reference plain cement mortar had a higher value for water immersion coefficient than mortars with the two types of ash. This is due to the fact that the reference mortar presented a higher water/binder ratio, which leads to mortars with higher porosity.

In general, the porosity decreased with the curing age. This was due to the increase of hydrated compound content and with the latent hydration during the pozzolanic reaction of ash in the presence of calcium hydroxide [50].

The replacement of coal fly ash by biomass fly ash did not lead to an improvement on the open porosity, for all curing ages. Using biomass fly ash or/and hydrated lime in mortars with coal fly ash lead to similar results to those observed in mortars only with cement and coal fly ash.

Fig. 6 shows the average values of the results obtained for the water absorption by capillarity for the three ages studied (28, 90 and 180 days). Based on the capillarity absorption, the corresponding coefficients were determined and are presented in Fig. 7.

The results showed that capillarity absorption is influenced by the water/binder ratio and by the binders used to produce mortars. The reference mortar presented the highest values for the capillarity absorption, and this is mainly due to the fact that this mortar was prepared with a 0.5 water/binder ratio. A higher water/binder ratio led to a production of a more porous material [51].

At 28 days, the replacement of cement by biomass fly ash did not lead to a better result in terms of capillarity absorption when compared with mortars with coal fly ash. However, when the two pozzolanic materials were used as a cement replacement,
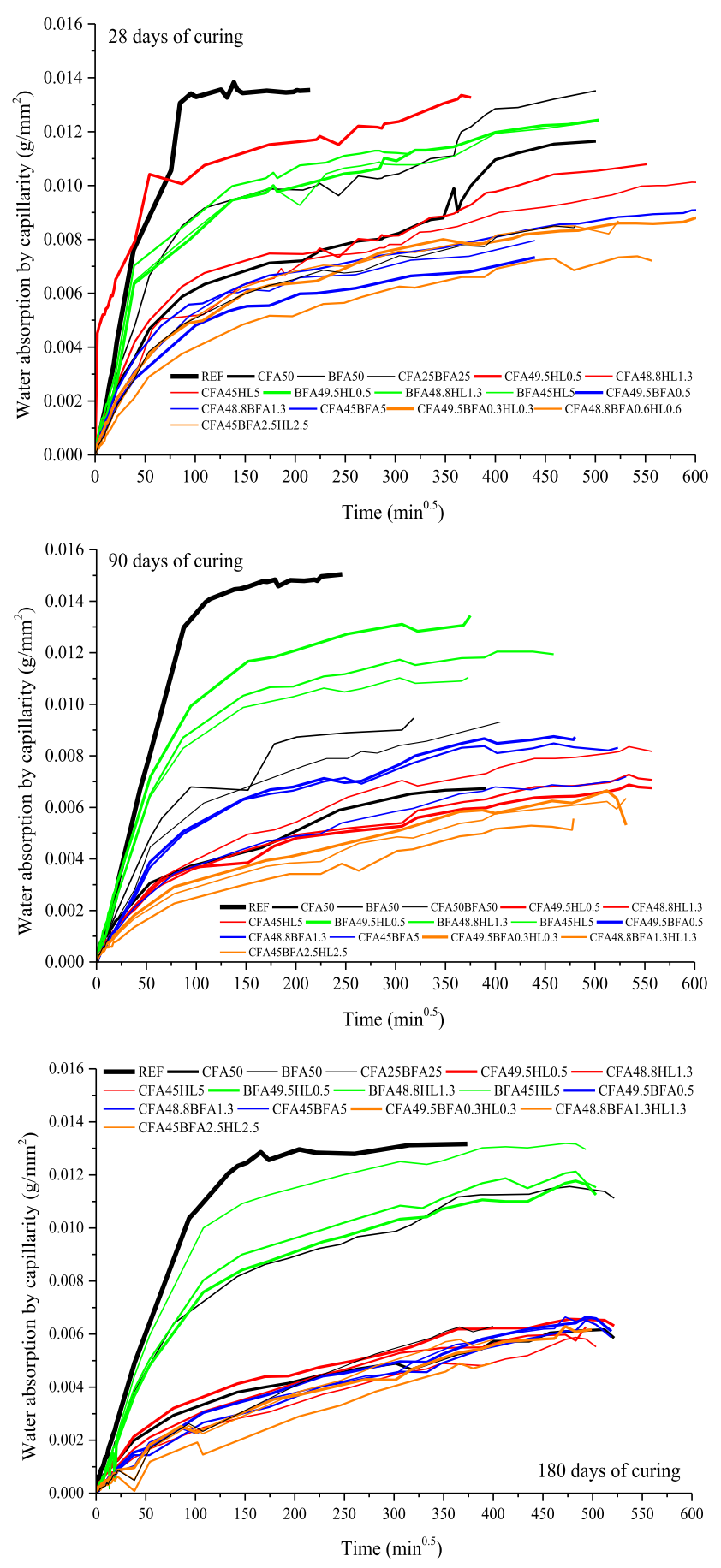

Fig. 6. Curves for the capillary absorption of mortars with 28, 90 and 180 days.

the produced mortars presented the lowest values for the water absorption capillarity tests. This reduction in the values is due to the CFA inclusion and its synergic effect with the biomass fly ash. The synergy between the two types of ash led to the pores blocking by physical actions due to the new products of pozzolanic reaction results in lower permeability mortars [52,53]. The synergic effect of coal fly ash with other pozzolanic materials and its effect on porosity was also observed in other studies [51].

The introduction of hydrated lime on mortar with biomass fly ash did not have a significant effect on the water absorption. However, in mortars with coal fly ash and $0.5 \%$ of HL lead to higher values of water absorption and the saturation point was achieved 


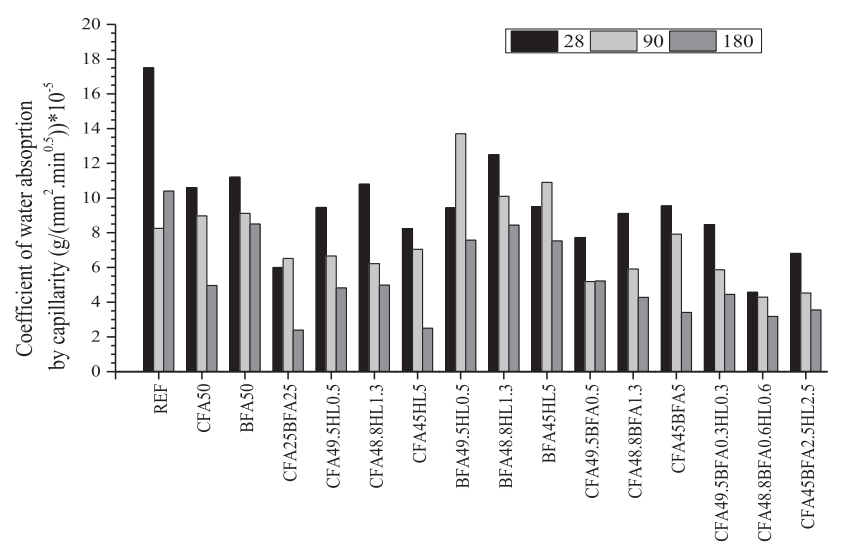

Fig. 7. Coefficient of water absorption by capillarity of mortars.

sooner than in the mortars with 1.25 or $5 \%$ of HL. The introduction of small quantities of biomass fly ash in mixes with cement and coal fly ash led to mortars with lower absorption values, which showed that these mortars have higher bulk density than mortars containing only coal fly ash. Similar results were observed when small quantities of biomass fly ash and hydrated lime were used in coal fly ash mortars.

It can be observed that, with the increase in the curing time (90 and 180 days), no significant differences between mortars with ash were noted. Using fly ash in construction materials, delays the cement hydration reaction and during the curing time, the calcium hydroxide dissolved in the water presented in mortar reacts with the fly ash to form solid reaction products that will fill the capillary pores partially or completely.

\subsubsection{Carbonation}

In Fig. 8, the depth of carbonation for the studied mortar formulation at 28,90,180, 270 and 360 days of curing is presented. As shown, the depth of carbonation increased with the duration of the carbonation test. For all curing ages, it is clear that the cement replacement by the two types of fly ash led to an increase in the rate of carbonation [54]. This might be due to the consumption of calcium hydroxide in the pozzolanic reaction, which occurs even before the initiation of carbonation. Due to the consumption of hydrates, the alkalinity of pore solution of mortars decreased [54].

The results related with the carbonation depth in each formulation were fitted to the classical expression, which relates the carbonation depth with the square root of time, to obtain the carbonation rate constant [55].

$X=V_{\mathrm{CO}_{2}} \sqrt{t}$

It is important to take into account that this expression does not consider other factors that affect the penetration of the carbonation front, such as the relative humidity and temperature $[55,56]$.

As can be observed in Table 8, the reference mortar presents the lower carbonation constant rate for all curing ages. This is due to the fact that cement mortars are less permeable to $\mathrm{CO}_{2}$ penetration than mortars with less cement. Mortars with pozzolanas had a higher consumption of $\mathrm{CH}$ and this led to a decrease in the alkalinity of mortar. The decrease in the alkalinity is one of the conditioning parameters for the development of the carbonation reaction [23,57].

In general, mortars with CFA and HL presented a decrease in the carbonation coefficient with the increase in the curing age (Fig. 8 and Table 8). A longer exposure time to the humidity cure leads to a higher hydration of cement, a smaller porosity, a reduction on permeability and consequently to a more compact microstruc- ture. In this case, the velocity of carbonation penetration is reduced [58].

The utilisation of biomass fly ash and hydrated lime was to mitigate the carbonation issue related to mortars with high cement replacement substitutions such the CFA50 mortar presented in this study. To do this, the carbonation rate of this mortar was compared with the rest of the studied mortars. Mortars with biomass fly ash/ hydrate lime mixed with coal fly ash presented values similar or lower than mortars with CFA. It is noted that the introduction of biomass fly ash leads to an increase in the alkalinity of mortars and has a good synergy with coal fly ash, which is reproduced in a lower carbonation rate and in a production of mortars with higher durability than the mortars with coal fly ash and cement as a binder. The good synergy between the two types of fly ash can also be related with the fact that the utilization of the two ashes together had an influence in the porosity of mortars (Figs. 5 and 7). This can lead to a conclusion that the lower carbonation rate can be also due to the packing effect that results when the two ashes are used together.

\subsubsection{Environmental assessment}

Table 9 presents the values obtained from the quantification of the environmental impact categories determined for each mortar formulation. The results showed that the reference mortar presents the highest values for all environmental impact categories. The high $\mathrm{CO}_{2}$ emission is related with the amount of cement, which is a result of clinker production $[59,60]$.

The results showed that the increase in the content of biomass fly ash in mortars leads to an increase in the values for the different environmental impact indicators. This is due to the fact that mortars with higher content of BFA need more superplasticizer to maintain similar workability (Table 4). The superplasticizer is a chemical admixture that has a significant impact on the LCA of mortars. It can also be observed that hydrated lime led to an increase on the environmental impact of the produced mortars. The mortar with $45 \%$ wt of BFA and 5\%wt of HL (BFA45HL5) presented higher values for the majority of the environmental impacts. However, using coal fly ash blended with small amounts of biomass fly ash led to the production of mortars with lower values on all environmental impact categories.

Table 10 presents the normalisation of the values obtained for each environmental impact category. The normalisation of the values allows a better understanding for each mortar that has a better environmental performance. It can be observed that the three mortars with coal fly ash blended with small amounts of biomass fly ash presented the best environmental performance (CFA49.5BFA0.5, CFA48.8BFA1.3 and CFA45BFA5).

Table 11 presents the sustainable profiles and the overall environmental performance for each mortar formulation. In the profiles, the shadowed area represents the performance of each mortar studied. At the level of each impact category, the best mortar is the one that has a value closest to one. It can be observed that CFA49.5BFA0.5, CFA48.8BFA1.3 and CFA45BFA5 mortars presented the best environmental performance and the reference mortar presented the worst performance.

The use of hydrated lime influences the environmental performance of mortars with coal and/or biomass fly ash. Moreover, mortars with high content of biomass fly ash did not present as good environmental performances as that of coal fly ash mortar. However, this is due to the fact that, to produce these mortars, the amount of superplasticizer increases significantly and this parameter leads to an increase on the environmental impacts.

It is important to mention that these results showed that using some of these formulations (essentially the formulations with coal fly ash blended with small amounts of biomass fly ash) to produce high volume fly ash mortar could lead to a production of a more 



Fig. 8. Carbonation depth measured in mortars with 28, 90, 180, 270 and 360 days curing.

eco-friendly construction material. This conclusion can be obtained, since the difference between the formulations presented in this study and the mortar formulations is the presence of gravel, and as the content of aggregates is almost similar for all formulations, their effect on the life cycle assessment will be the same for all formulations, where the binder part of mortar is the most important parameter for the LCA. The possibility of producing of a material with a better environmental performance can be a solution for the sustainability of mortar and concrete industry.

\section{Conclusions}

One of the solutions to mitigate the problems of high volume of fly ash mortar can be using small amount of biomass fly ash blended with coal fly ash. Since, the use of small amounts of biomass fly ash on mortars with high volume coal fly ash content leads to a production of mortars with similar quality properties than mortars with coal fly ash, showing a good synergy between the two ashes. BFA blended with CFA seems to have a positive 
Table 8

Carbonation rate constant for the different mortar formulations for the different curing periods

\begin{tabular}{|c|c|c|c|c|c|}
\hline \multirow[t]{2}{*}{ Samples } & 28 days & 90 days & 180 days & 270 days & 360 days \\
\hline & \multicolumn{5}{|c|}{$\mathrm{mm} / \mathrm{min}^{0.5}$} \\
\hline REF & 0.77 & 0.77 & 0.68 & 0.77 & 0.76 \\
\hline CFA50 & 1.40 & 1.59 & 1.34 & 1.31 & 1.31 \\
\hline BFA50 & 2.19 & 1.88 & 1.66 & 1.66 & 1.98 \\
\hline CFA25BFA25 & 1.61 & 1.86 & 1.41 & 1.48 & 1.40 \\
\hline CFA49.5HL0.5 & 1.40 & 1.28 & 1.29 & 1.30 & 1.41 \\
\hline CFA48.8HL1.3 & 1.43 & 1.33 & 1.27 & 1.38 & 1.54 \\
\hline CFA45HL5 & 1.35 & 1.28 & 1.19 & 1.21 & 1.13 \\
\hline BFA49.5HL0.5 & 1.74 & 1.61 & 1.71 & 1.97 & 1.68 \\
\hline BFA48.8HL1.3 & 1.89 & 1.69 & 1.86 & 1.47 & 1.61 \\
\hline BFA45HL5 & 1.73 & 1.49 & 1.47 & 1.52 & 1.56 \\
\hline CFA49.5BFA0.5 & 1.34 & 1.39 & 1.25 & 1.26 & 1.21 \\
\hline CFA48.8BFA1.3 & 1.43 & 1.46 & 1.23 & 1.34 & 1.26 \\
\hline CFA45BFA5 & 1.48 & 1.32 & 1.24 & 1.28 & 1.37 \\
\hline CFA49.5BFA0.3HL0.3 & 1.50 & 1.32 & 1.22 & 1.34 & 1.27 \\
\hline CFA48.8BFA0.6HL0.6 & 1.33 & 1.28 & 1.25 & 1.26 & 1.30 \\
\hline CFA45BFA2.5HL2.5 & 1.39 & 1.33 & 1.36 & 1.44 & 1.33 \\
\hline
\end{tabular}

Table 9

Values obtained for the different envrionmaental impact indicator for each mortar formulation.

\begin{tabular}{|c|c|c|c|c|c|c|}
\hline \multirow[t]{2}{*}{ Mortar Formulations } & \multicolumn{6}{|c|}{ Environmental impact categories } \\
\hline & $\begin{array}{l}\text { GWP100 } \\
{\left[\mathrm{kg} \mathrm{CO} \mathrm{CO}_{2} \text { eq] }\right.}\end{array}$ & $\begin{array}{l}\text { ODP } \\
\text { [kg CFC-11 eq] }\end{array}$ & $\begin{array}{l}\mathrm{AP} \\
{\left[\mathrm{kg} \mathrm{SO} \mathrm{S}_{2} \mathrm{eq}\right]}\end{array}$ & $\begin{array}{l}\mathrm{EP} \\
{\left[\mathrm{kg} \mathrm{PO}_{4} \mathrm{eq}\right]}\end{array}$ & $\begin{array}{l}\text { POCP } \\
{\left[\mathrm{kg} \mathrm{C}_{2} \mathrm{H}_{4} \text { eq] }\right.}\end{array}$ & $\begin{array}{l}\text { ADP_FF } \\
\text { [MJ eq] }\end{array}$ \\
\hline REF & $5.66 \mathrm{E}+02$ & $2.70 \mathrm{E}-05$ & $1.29 \mathrm{E}+00$ & $3.26 \mathrm{E}-01$ & $5.20 \mathrm{E}-02$ & $3.06 \mathrm{E}+03$ \\
\hline CFA50 & $3.41 \mathrm{E}+02$ & $1.94 \mathrm{E}-05$ & $8.72 \mathrm{E}-01$ & $2.33 \mathrm{E}-01$ & $3.61 \mathrm{E}-02$ & $2.27 \mathrm{E}+03$ \\
\hline BFA50 & $3.56 \mathrm{E}+02$ & $2.05 \mathrm{E}-05$ & $9.42 \mathrm{E}-01$ & $2.36 \mathrm{E}-01$ & $4.01 \mathrm{E}-02$ & $2.61 \mathrm{E}+03$ \\
\hline CFA25BFA25 & $3.36 \mathrm{E}+02$ & $1.90 \mathrm{E}-05$ & $8.27 \mathrm{E}-01$ & $2.19 \mathrm{E}-01$ & $3.47 \mathrm{E}-02$ & $2.02 \mathrm{E}+03$ \\
\hline CFA49.5HL0.5 & $3.33 \mathrm{E}+02$ & $1.88 \mathrm{E}-05$ & $8.10 \mathrm{E}-01$ & $2.22 \mathrm{E}-01$ & $3.38 \mathrm{E}-02$ & $2.10 \mathrm{E}+03$ \\
\hline CFA48.8HL1.3 & $3.37 \mathrm{E}+02$ & $1.91 \mathrm{E}-05$ & $8.16 \mathrm{E}-01$ & $2.23 \mathrm{E}-01$ & $3.47 \mathrm{E}-02$ & $2.11 \mathrm{E}+03$ \\
\hline CFA45HL5 & $3.53 \mathrm{E}+02$ & $2.00 \mathrm{E}-05$ & $8.41 \mathrm{E}-01$ & $2.27 \mathrm{E}-01$ & $3.79 \mathrm{E}-02$ & $2.18 \mathrm{E}+03$ \\
\hline BFA49.5HL0.5 & $3.58 \mathrm{E}+02$ & $2.06 \mathrm{E}-05$ & $9.44 \mathrm{E}-01$ & $2.36 \mathrm{E}-01$ & $4.05 \mathrm{E}-02$ & $2.51 \mathrm{E}+03$ \\
\hline BFA48.8HL1.3 & $3.62 \mathrm{E}+02$ & $2.09 \mathrm{E}-05$ & $9.51 \mathrm{E}-01$ & $2.38 \mathrm{E}-01$ & $4.14 \mathrm{E}-02$ & $2.53 E+03$ \\
\hline BFA45HL5 & $3.66 \mathrm{E}+02$ & $2.11 \mathrm{E}-05$ & $9.57 \mathrm{E}-01$ & $2.39 \mathrm{E}-01$ & $4.23 \mathrm{E}-02$ & $2.55 \mathrm{E}+03$ \\
\hline CFA49.5BFA0.5 & $3.31 \mathrm{E}+02$ & $1.87 \mathrm{E}-05$ & $8.07 \mathrm{E}-01$ & $2.22 \mathrm{E}-01$ & $3.34 \mathrm{E}-02$ & $2.09 \mathrm{E}+03$ \\
\hline CFA48.8BFA1.3 & $3.31 \mathrm{E}+02$ & $1.87 \mathrm{E}-05$ & $8.07 \mathrm{E}-01$ & $2.21 \mathrm{E}-01$ & $3.34 \mathrm{E}-02$ & $2.08 \mathrm{E}+03$ \\
\hline CFA45BFA5 & $3.31 \mathrm{E}+02$ & $1.87 \mathrm{E}-05$ & $8.06 \mathrm{E}-01$ & $2.20 \mathrm{E}-01$ & $3.34 \mathrm{E}-02$ & $2.07 \mathrm{E}+03$ \\
\hline CFA49.5BFA0.3HL0.3 & $3.39 \mathrm{E}+02$ & $1.92 \mathrm{E}-05$ & $8.35 \mathrm{E}-01$ & $2.29 \mathrm{E}-01$ & $3.53 \mathrm{E}-02$ & $2.09 \mathrm{E}+03$ \\
\hline CFA49.5BFA0.6HL0.6 & $3.38 \mathrm{E}+02$ & $1.92 \mathrm{E}-05$ & $8.34 \mathrm{E}-01$ & $2.29 \mathrm{E}-01$ & $3.52 \mathrm{E}-02$ & $2.08 \mathrm{E}+03$ \\
\hline CFA48.8BFA2.5HL2.5 & $3.48 \mathrm{E}+02$ & $1.98 \mathrm{E}-05$ & $8.49 \mathrm{E}-01$ & $2.30 \mathrm{E}-01$ & $3.73 \mathrm{E}-02$ & $2.06 \mathrm{E}+03$ \\
\hline
\end{tabular}

Table 10

Normalised values of the studied environmental impact categories.

\begin{tabular}{|c|c|c|c|c|c|c|}
\hline \multirow[t]{2}{*}{ Mortar Formulations } & \multicolumn{6}{|c|}{ Environmental impact categories } \\
\hline & $\begin{array}{l}\text { GWP100 } \\
{\left[\mathrm{kg} \mathrm{CO} \mathrm{CO}_{2} \mathrm{eq}\right]}\end{array}$ & $\begin{array}{l}\text { ODP } \\
{[\mathrm{kg} \text { CFC-11 eq] }}\end{array}$ & $\begin{array}{l}\mathrm{AP} \\
{\left[\mathrm{kg} \mathrm{SO} \mathrm{S}_{2} \mathrm{eq}\right]}\end{array}$ &  & $\begin{array}{l}\text { РOCP } \\
{\left[\mathrm{kg} \mathrm{C}_{2} \mathrm{H}_{4} \text { eq] }\right.}\end{array}$ & $\begin{array}{l}\text { ADP_FF } \\
\text { [MJ eq] }\end{array}$ \\
\hline REF & 0.00 & 0.00 & 0.00 & 0.00 & 0.00 & 0.00 \\
\hline CFA50 & 0.96 & 0.91 & 0.86 & 0.88 & 0.86 & 0.76 \\
\hline BFA50 & 0.90 & 0.78 & 0.72 & 0.85 & 0.64 & 0.43 \\
\hline CFA25BFA25 & 0.98 & 0.97 & 0.96 & 1.00 & 0.93 & 1.00 \\
\hline CFA49.5HL0.5 & 0.99 & 0.98 & 0.99 & 0.97 & 0.98 & 0.93 \\
\hline CFA48.8HL1.3 & 0.97 & 0.95 & 0.98 & 0.96 & 0.93 & 0.91 \\
\hline CFA45HL5 & 0.91 & 0.84 & 0.93 & 0.93 & 0.75 & 0.85 \\
\hline BFA49.5HL0.5 & 0.89 & 0.77 & 0.71 & 0.84 & 0.62 & 0.53 \\
\hline BFA48.8HL1.3 & 0.87 & 0.74 & 0.70 & 0.83 & 0.57 & 0.51 \\
\hline BFA45HL5 & 0.85 & 0.71 & 0.68 & 0.82 & 0.52 & 0.49 \\
\hline CFA49.5BFA0.5 & 1.00 & 1.00 & 1.00 & 0.98 & 1.00 & 0.94 \\
\hline CFA48.8BFA1.3 & 1.00 & 1.00 & 1.00 & 0.98 & 1.00 & 0.94 \\
\hline CFA45BFA5 & 1.00 & 1.00 & 1.00 & 1.00 & 1.00 & 0.95 \\
\hline CFA49.5BFA0.3HL0.3 & 0.97 & 0.93 & 0.94 & 0.91 & 0.90 & 0.94 \\
\hline CFA49.5BFA0.6HL0.6 & 0.97 & 0.94 & 0.94 & 0.91 & 0.90 & 0.94 \\
\hline CFA48.8BFA2.5HL2.5 & 0.93 & 0.87 & 0.91 & 0.90 & 0.79 & 0.96 \\
\hline
\end{tabular}


Table 11

Normalised values that described the global assessment of each mortar formulation.

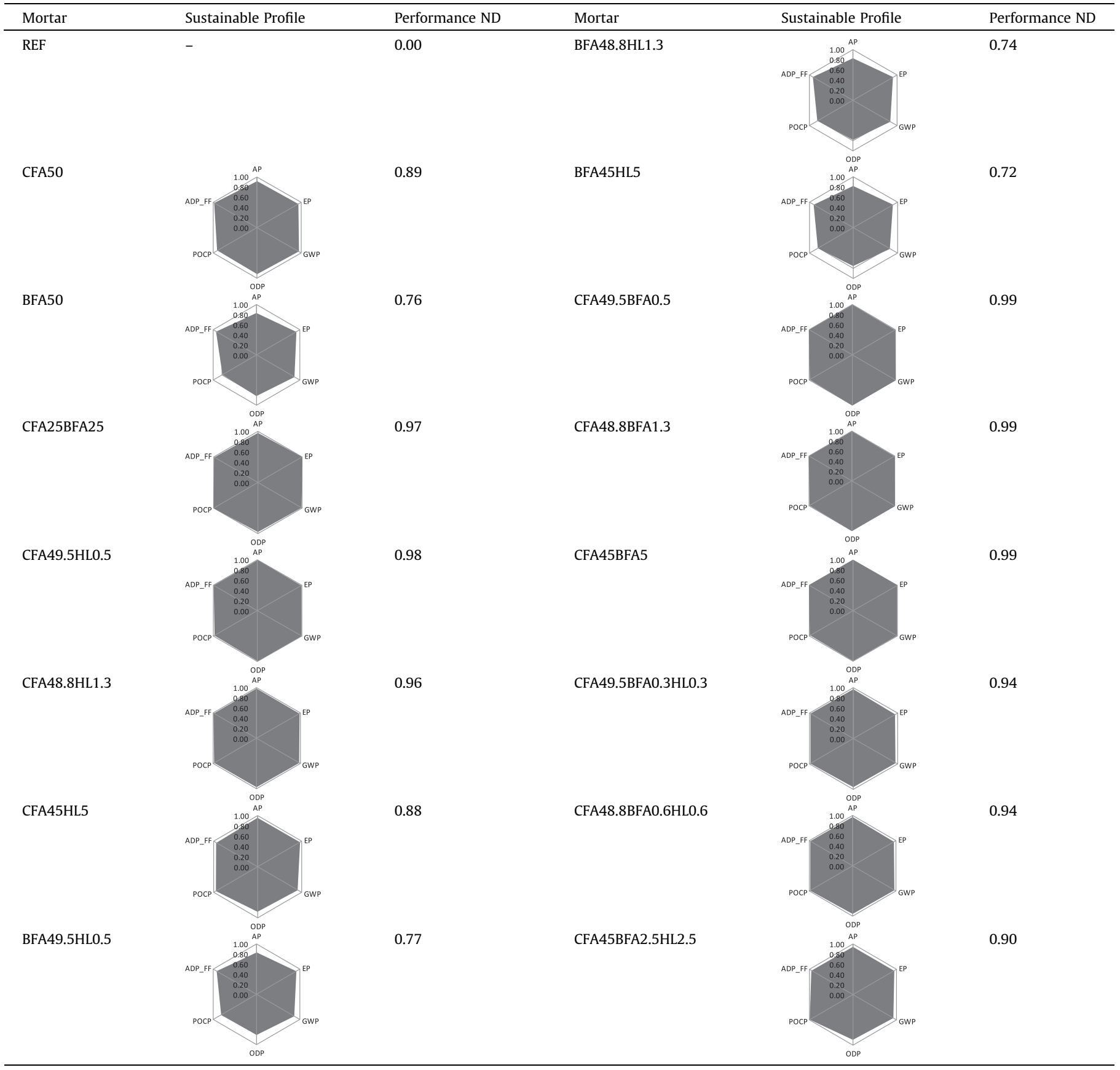

contribution on the durability of mortar when compared with mortar with only coal fly ash as supplementary cementitious material, but essentially with a better environmental performance than a plain cement mortar, leading to a production of a more ecoefficient material.

This work studied the effect of cement replacement by coal and biomass fly ash on the quality, durability and environmental performance of mortars. This study also attempts to understand if slight amounts of hydrated lime or biomass fly ash (an alkaline waste) have a contribution for the problems related to mortar with a high amount of cement replacement by coal fly ash, mainly the carbonation issue.

The study showed that biomass fly ash has an influence on the workability and to maintain a similar flow spread the superplasti- cizer dosage needed to be increased. Replacing cement by CFA, BFA or/and a blend of the two different types of ash led to similar or higher values on the flexural strength, when compared with the mortar made only with cement. It was observed that both type of fly ash retarded the gain of compressive strength, but after 90 days of curing, the CFA mortar and the mortar with a blended of BFA and CFA presented similar values to the reference. Thus, one can produce similar mortars/concrete than plain cement mortars/concrete, but with half of cement content. It is important to note that using BFA and hydrated lime in the same mixture does not lead to mortars with good mechanical resistance. However, mortars with fly ash blended with low biomass fly ash content lead to higher values of compressive strength than when just coal fly ash is used as cement replacement material. 
The replacement of coal fly ash by biomass fly ash did not lead to an improvement on the open porosity, for all curing ages. Using biomass fly ash or/and hydrated lime in mortars with coal fly ash leads to similar results to those observed in cement and coal fly ash.

The introduction of small quantities of biomass fly ash in mixes with cement and coal fly ash produced mortars with lower water absorption by capillarity values, which showed that these mortars have less porosity than the mortars only with coal fly ash.

Cement replacement by fly ash led to an increased on the rate of carbonation. Reference plain cement mortar presents the lower carbonation constant rate for all curing ages. Mortars with fly ash and with hydrated lime presented a decrease in the carbonation coefficient with the increase in the curing age. Mortars with biomass fly ash/hydrate lime mixed with coal fly ash presented similar values or lower than mortars with coal fly ash. It is noted that the introduction of biomass fly ash leads to an increase in the alkalinity of mortars and has a good synergy with coal fly ash, which is reproduced in a lower carbonation rate.

In terms of sustainable performance, the CFA49.5BFA0.5, CFA48.8BFA1.3 and CFA45BFA5 mortars presented the best environmental performance and the reference mortar presented the worst performance. The utilisation of hydrated lime influences the environmental performance of mortars with coal and/or biomass fly ash. Moreover, mortars with a high content of biomass fly ash did not present a good environmental performance when compared with coal fly ash mortar. However, this is due to the fact that to produce these mortars, the amount of superplasticizer increases significantly, and this parameter leads to an increase in the environmental impacts.

\section{Conflict of interest}

None.

\section{Acknowledgements}

The authors wish to thank the Portuguese Foundation for Science and Technology (FCT) and the Eco-Construction and Rehabilitation Doctoral Program for supporting the PhD scholarship (reference PD/BD/52661/2014). This work was also financed by FEDER funds through the Competitivity Factors Operational Programme - COMPETE and by national funds through FCT - Foundation for Science and Technology within the scope of the project POCI-01- 0145-FEDER- 007633 and through the Regional Operational Programme CENTRO2020 within the scope of the project CENTRO-01- 0145-FEDER- 000006.

\section{References}

[1] R.J. Flatt, N. Roussel, C.R. Cheeseman, Concrete: an eco material that needs to be improved, J. Eur. Ceram. Soc. 32 (2012) 2787-2798, https://doi.org/10.1016/ j.jeurceramsoc.2011.11.012.

[2] K. Celik, C. Meral, A. Petek Gursel, P.K. Mehta, A. Horvath, P.J.M. Monteiro, Mechanical properties, durability, and life-cycle assessment of selfconsolidating concrete mixtures made with blended Portland cements containing fly ash and limestone powder, Cem. Concr. Compos. 56 (2015) 59-72, https://doi.org/10.1016/j.cemconcomp.2014.11.003.

[3] H.S. Lee, X.Y. Wang, Evaluation of the carbon dioxide uptake of slag-blended concrete structures, considering the effect of carbonation, Sustainability 8 (2016) 1-18, https://doi.org/10.3390/su8040312.

[4] C.D. Tomkins, Redefining What's Possible for Clean Energy by 2020, Gigaton Throwdown, San Francisco, 2009.

[5] P.K. Mehta, Global concrete industry sustainability, Concr. Int. 31 (2009) 4548.

[6] P. Chindaprasirt, S. Rukzon, V. Sirivivatnanon, Effect of carbon dioxide on chloride penetration and chloride ion diffusion coefficient of blended Portland cement mortar, Constr. Build. Mater. 22 (2008) 1701-1707, https://doi.org/ 10.1016/j.conbuildmat.2007.06.002.
[7] I. Monteiro, F.A. Branco, J. De Brito, R. Neves, Statistical analysis of the carbonation coefficient in open air concrete structures, Constr. Build. Mater. 29 (2012) 263-269, https://doi.org/10.1016/j.conbuildmat.2011.10.028.

[8] S. Chowdhury, M. Mishra, O. Suganya, The incorporation of wood waste ash as a partial cement replacement material for making structural grade concrete: an overview, Ain Shams Eng. J. 6 (2015) 429-437, https://doi.org/10.1016/j. asej.2014.11.005.

[9] A.U. Elinwa, Y.A. Mahmood, Ash from timber waste as cement replacement material, Cem. Concr. Compos. 24 (2002) 219-222, https://doi.org/10.1016/ S0958-9465(01)00039-7.

[10] S.V. Vassilev, D. Baxter, L.K. Andersen, C.G. Vassileva, An overview of the composition and application of biomass ash. Part 1. Phase-mineral and chemical composition and classification, Fuel 105 (2013) 40-76, https://doi. org/10.1016/j.fuel.2012.09.041.

[11] F.F. Udoeyo, H. Inyang, D.T. Young, E.E. Oparadu, Potential of wood waste ash as an additive in concrete, J. Mater. Civ. Eng. 18 (2006) 605-611, https://doi. org/10.1061/(ASCE)0899-1561(2006) 18:4(605).

[12] S. Wang, L. Baxter, Comprehensive study of biomass fly ash in concrete: strength, microscopy, kinetics and durability, Fuel Process. Technol. 88 (2007) 1165-1170, https://doi.org/10.1016/j.fuproc.2007.06.016.

[13] M. Cruz-Yusta, I. Mármol, J. Morales, L. Sánchez, Use of olive biomass fly-ash in the preparation of environmental friendly mortars, Environ. Sci. Technol. 45 (2011) 6991-6996.

[14] R. Feiz, J. Ammenberg, L. Baas, M. Eklund, A. Helgstrand, R. Marshall, Improving the CO2 performance of cement, part I: utilizing life-cycle assessment and key performance indicators to assess development within the cement industry, J. Cleaner Prod. 98 (2015) 272-281, https://doi.org/10.1016/j. jclepro.2014.01.083.

[15] C.K. Chau, T.M. Leung, W.Y. Ng, A review on life cycle assessment, life cycle energy assessment and life cycle carbon emissions assessment on buildings, Appl. Energy 143 (2015) 395-413, https://doi.org/10.1016/j. apenergy.2015.01.023.

[16] E.R. Teixeira, A. Camões, F.G. Branco, L. Tarelho, Biomass and coal fly ash as cement replacement on mortar properties, in: ICCS16 - II Int. Conf. Concr. Sustain., Madrid, Spain, 2016: pp. 1-12.

[17] ASTM C188-95, Standard Test Method for Density of Hydraulic Cement 1, ASTM International, 2003. doi:10.1520/C0188-09.2.

[18] EN 450-1, Norma Portuguesa, Cinzas volantes para betão, Parte 1: definição, especificações e critérios de conformidade (Portuguese Norm, Fly ash concrete, Part 1: Definition, specifications and conformity criteria), Instituto Português da Qualidade, 2012.

[19] C.C. Ban, M. Ramli, The implementation of wood waste ash as a partial cement replacement material in the production of structural grade concrete and mortar: an overview, Resour. Conserv. Recycl. 55 (2011) 669-685, https://doi. org/10.1016/j.resconrec.2011.02.002.

[20] R. Barbosa, N. Lapa, D. Dias, B. Mendes, Concretes containing biomass ashes: mechanical, chemical, and ecotoxic performances, Constr. Build. Mater. 48 (2013) 457-463, https://doi.org/10.1016/j.conbuildmat.2013.07.031.

[21] R. Rajamma, R.J. Ball, L.A.C. Tarelho, G.C. Allen, J.A. Labrincha, V.M. Ferreira, Characterisation and use of biomass fly ash in cement-based materials, J. Hazard. Mater. 172 (2009) 1049-1060, https://doi.org/10.1016/j. jhazmat.2009.07.109.

[22] A. Vimmrová, M. Keppert, O. Michalko, R. Černý, Calcined gypsum-limemetakaolin binders: design of optimal composition, Cem. Concr. Compos. 52 (2014) 91-96, https://doi.org/10.1016/j.cemconcomp.2014.05.011.

[23] R. Reis, A. Camões, M. Ribeiro, R. Malheiro, Matrizes cimentíceas com elevado volume de cinzas volantes e hidróxido de cálcio: estudo da carbonatação, 5as Jornadas Port. Eng. Estruturas (2014) 1-12.

[24] EN 1015-3, European Standard, Methods of Test for Mortar for Masonry - Part 3: Determination of Consistence of Fresh Mortar (By Flow Table), CEN, Brussels, 1998.

[25] NP EN 1015-2, European Standard, Methods of test for mortar for Mansonary Part 2: Bulk sampling of mortars and preparation of test mortars, 1998.

[26] EN 1015-7, European Standard, Methods of Test for Mortar for Masonry - Part 7: Determination of Air Content of Fresh Mortar, CEN, Brussels, 1998.

[27] EN 1015-11, European Standard, Methods of Test for Mortar for Masonry Part 11: Determination of Flexural and Compressive Strength of Hardened Mortar, CEN, Brussels, 1999.

[28] EN 1015-10, European Standard, Methods of Test for Mortar for Masonry Part 10: Determination of Dry Bulk Density of Hardened Mortar, CEN, Brussels, 1999.

[29] LNEC E 394, Especificação LNEC - Determinação da absorção de água por imersão (LNEC Specification - Determination of the absorption of water immersion), Laboratório Nacional de Engenharia Civil, Portugal, 1993.

[30] EN 1015-18, European Standard, Methods of Test for Mortar for Masonry Part 18: Determination of Water Absorption Coefficient Due to Capillary Action of Hardened Mortar, CEN, Brussels, 2002.

[31] CEN/TS 12390-12, Testing Hardened Concrete - Part 12: Determination of the Potential Carbonation Resistance of Concrete: Accelerated Carbonation Method, CEN, Brussels, 2010.

[32] J. Khunthongkeaw, S. Tangtermsirikul, T. Leelawat, A study on carbonation depth prediction for fly ash concrete, Constr. Build. Mater. 20 (2006) 744-753, https://doi.org/10.1016/j.conbuildmat.2005.01.052.

[33] R. Mateus, L. Bragança, Tecnologias Construtivas para a Sustentabilidade da Construção (in English Building Technologies for Sustainable Construction), Porto, 2010. 
[34] R. Mateus, S. Neiva, L. Bragança, P. Mendonça, M. Macieira, Sustainability assessment of an innovative lightweight building technology for partition walls - comparison with conventional technologies, Build. Environ. 67 (2013) 147-159, https://doi.org/10.1016/j.buildenv.2013.05.012.

[35] E.R. Teixeira, R. Mateus, A.F. Camões, L. Bragança, F.G. Branco, Comparative environmental life-cycle analysis of concretes using biomass and coal fly ashes as partial cement replacement material, J. Cleaner Prod. 112 (2016) 2221 2230, https://doi.org/10.1016/j.jclepro.2015.09.124.

[36] X. Li, Y. Zhu, Z. Zhang, An LCA-based environmental impact assessment model for construction processes, Build. Environ. 45 (2010) 766-775, https://doi.org/ 10.1016/j.buildenv.2009.08.010.

[37] Secil - Companhia Geral de Cal e Cimentos, Declaração ambiental intercalar 2015 Cibra-Pataias, 2015.

[38] P. Van Den Heede, N. De Belie, Environmental impact and life cycle assessment (LCA) of traditional and "green" concretes: Literature review and theoretica calculations, Cem. Concr. Compos. 34 (2012) 431-442, https://doi.org/ 10.1016/j.cemconcomp.2012.01.004.

[39] ISO 14040, Environmental management - Life cycle assessment - Principles and framework, 2006

[40] R. Hischier, B. Weidema, H. Althaus, C. Bauer, G. Doka, R. Dones, R. Frischknecht, S. Hellweg, S. Humbert, N. Jungbluth, T. Köllner, Y. Loerincik, M. Margni, T. Nemecek, Implementation of Life Cycle Impact Assessment Methods. Ecoinvent report No. 3, v2.2, 2010.

[41] F.P. Torgal, S. Jalali, Eco-efficient Construction and Building Materials: Life Cycle Assessment (LCA), Eco-Labelling and Case Studies, Woodhead Publishing Series in Civil and Structural Engineering, 2011. doi:10.1007/978-0-85729892-8.

[42] F.P. Torgal, S. Jalali, Construção Sustentável. O caso dos materiais de construção, in: Congr. Construção 2007 - 3Congr. Nac., Coimbra, 2007, pp. $1-10$.

[43] CEN EN 15804:2012, Sustainability of Construction Works - Environmental Product Declarations - Core Rules for the Product Category of Construction Products, CEN, Brussels, 2012.

[44] R. Rajamma, L. Senff, M.J. Ribeiro, J.A. Labrincha, R.J. Ball, G.C. Allen, V.M Ferreira, Biomass fly ash effect on fresh and hardened state properties of cement based materials, Composites Part B 77 (2015) 1-9, https://doi.org/ 10.1016/j.compositesb.2015.03.019.

[45] R.C.E. Modolo, V.M. Ferreira, L.A. Tarelho, J.A. Labrincha, L. Senff, L. Silva, Mortar formulations with bottom ash from biomass combustion, Constr. Build. Mater. $45 \quad$ (2013) 275-281, https://doi.org/10.1016/ j.conbuildmat.2013.03.093.

[46] M. Berra, T. Mangialardi, A.E. Paolini, Reuse of woody biomass fly ash in cement-based materials, Constr. Build. Mater. 76 (2015) 286-296, https://doi. org/10.1016/j.conbuildmat.2014.11.052.

[47] K.H. Yang, A.R. Cho, J.K. Song, Effect of water-binder ratio on the mechanical properties of calcium hydroxide-based alkali-activated slag concrete, Constr.
Build. Mater. 29 j.conbuildmat.2011.10.062.

[48] S.A. Barbhuiya, J.K. Gbagbo, M.I. Russell, P.A.M. Basheer, Properties of fly ash concrete modified with hydrated lime and silica fume, Constr. Build. Mater. 23 (2009) 3233-3239, https://doi.org/10.1016/j.conbuildmat.2009.06.001.

[49] Y. Aggarwal, R. Siddique, Microstructure and properties of concrete using bottom ash and waste foundry sand as partial replacement of fine aggregates, Constr. Build. Mater. 54 (2014) 210-223, https://doi.org/10.1016/ j.conbuildmat.2013.12.051.

[50] R. Rajamma, Incorporação de cinzas volantes de biomassa em materiais cimentíceos (Biomass fly ash incorporation in cement based materials) PhD Thesis, Departamento de Engenharia Cerêmica e do Vidro. Universidade de Aveiro, 2011.

[51] X. Chen, S. Wu, Influence of water-to-cement ratio and curing period on pore structure of cement mortar, Constr. Build. Mater. 38 (2013) 804-812, https:// doi.org/10.1016/j.conbuildmat.2012.09.058.

[52] H.N. Atahan, O.N. Oktar, M.A. Taşdemir, Effects of water-cement ratio and curing time on the critical pore width of hardened cement paste, Constr. Build. Mater. $23 \quad$ (2009) 1196-1200, https://doi.org/10.1016/ j.conbuildmat.2008.08.011.

[53] R.C. Joshi, R.P. Lohita, Fly ash in concrete: production, properties and uses, 2001 Int. Ash Util. Symp., Center for Applied Energy Research, University of Kentuck, 2001.

[54] S. Hussain, D. Bhunia, S.B. Singh, Comparative study of accelerated carbonation of plain cement and fly-ash concrete, J. Build. Eng. 10 (2017) 26-31, https:// doi.org/10.1016/j.jobe.2017.02.001.

[55] E. Zornoza, J. Payá, J. Monzó, M.V. Borrachero, P. Garcés, The carbonation of OPC mortars partially substituted with spent fluid catalytic catalyst (FC3R) and its influence on their mechanical properties, Constr. Build. Mater. 23 (2009) 1323-1328, https://doi.org/10.1016/j.conbuildmat.2008.07.024.

[56] M.A. Sanjuán, C. Andrade, M. Cheyrezy, Concrete carbonation tests in natural and accelerated conditions, Adv. Cem. Res. 15 (2003) 171-180, https://doi.org/ 10.1680/adcr.2003.15.4.171.

[57] T. Ramos, A.M. Matos, J. Sousa-Coutinho, Strength and durability of mortar using cork waste ash as cement replacement, Mater. Res. 17 (2014) 893-907, https://doi.org/10.1590/S1516-14392014005000092.

[58] M.D.A. Thomas, J.D. Matthews, Carbonation of fly ash concrete, Mag. Concr. Res. 44 (1992) 217-228, https://doi.org/10.1680/macr.1992.44.160.217.

[59] C.-Y. Zhang, R. Han, B. Yu, Y.-M. Wei, Accounting process-related $\mathrm{CO} 2$ emissions from global cement production under Shared Socioeconomic Pathways, J. Cleaner Prod. 184 (2018) 451-465, https://doi.org/10.1016/j. jclepro.2018.02.284.

[60] Z. Cao, L. Shen, J. Zhao, L. Liu, S. Zhong, Y. Yang, Modeling the dynamic mechanism between cement $\mathrm{CO} 2$ emissions and clinker quality to realize lowcarbon cement, Resour. Conserv. Recycl. 113 (2016) 116-126, https://doi.org/ 10.1016/j.resconrec.2016.06.011. 